\title{
Sportcivilek-ellenőrzés, beszámolási sajátosságok
}

\section{Civic Organizations, Sports Civic Organizations and the Control}

\author{
Szabados Gy. N. ${ }^{1}$, BÁcsné B. É. ${ }^{2}$, Fenyves V. ${ }^{3}$, BÁcs Z. ${ }^{4}$, HelmecZi A. ${ }^{5}$, DAJNOKI K. ${ }^{6}$ \\ 1Debreceni Egyetem, Gazdaságtudományi Kar, Szervezés és Kommunikáció Tanszék, szaba- \\ dos.gyorgy@con.unideb.hu \\ ²Debreceni Egyetem, Gazdaságtudományi Kar, Sportgazdasági- és Menedzsment Tanszék, bacs- \\ ne.baba.eva@econ.unideb.hu \\ 3Debreceni Egyetem Gazdaságtudományi Kar, Kontrolling Tanszék, fenyves.veronika@econ.unideb.hu \\ ${ }^{4}$ Debreceni Egyetem Gazdaságtudományi Kar, Számviteli Tanszék, bacs.zoltan@econ.unideb.hu \\ ${ }^{5}$ Debreceni Egyetem, Gazdaságtudományi Kar, Gazdasági Jog Tanszék, helmeczi.andras@econ.unideb.hu \\ ${ }^{6}$ Debreceni Egyetem, Gazdaságtudományi Kar, Emberi Erőforrás Menedzsment Tanszék, dajno- \\ ki.krisztina@econ.unideb.hu
}

\section{A publikáció elkészítését a EFOP-3.6.2-16-2017-00003 számú projekt támogatta. A projekt az Európai Unió támogatásával, az Európai Szociális Alap társfinanszírozásával valósult meg.}

Absztrakt. Az ellenörzés, mint vezetési funkció nem mondható egy, a vezetési szakirodalmakban különösen preferált vizsgálati témának, hasonlóan igaz ez a civil szervezetek témakörére is. Magyarországon a rendszerváltást követően intenzívvé váló nonprofit, azon belül pedig a civil szféra lényegesen meghatározóvá vált. 2017-ben a 61151 nonprofit szervezet 15,2\%-a sport cél szerinti tevékenységü, az 53613 klasszikus civil szervezet (egyesületek és alapítványok) esetében ez az arány magasabb, 16,2\%. Ezeknek a szervezeteknek különös sajátossága a támogatásokkal kapcsolatos különös összefüggés, mely a KSH aktuális adatai szerint mára támogatásfüggőséggé vált (a bevételek közel 2/3-a támogatás). Ezért válhat érzékennyé a téma, amennyiben egy szervezet ugyanis nem tud elszámolni támogatásokkal, vagy nem tud megfelelni a törvényi elvárásoknak, úgy az összefüggésben lehet a vezetố ellenörzői funkciójával, és rávilágít a civil szervezetek és az ellenőrzés összefüggésére. Tanulmányunkban az ellenörzés mint vezetési funkción keresztül kívánjuk röviden áttekinteni a téma sajátosságait, ahol eredményeink szerint ezek a szervezetek egy jelentős része nem is igazán tud az elvárásoknak megfelelően teljesiteni.

Abstract. Control, az a managerial function cannot be considered as one of the most frequently preferred examinational topics, and it is also valid for the matter of civic organization. Nevertheless, we must not forget about the increasing number and intensive non-profit sphere after the change of the regime, where the civic sphere inside has become determinant. In 2017, 15,2\% of the 61151 nonprofit organizations had a sport profile, and this ratio is higher, 16,2\% regarding the 53613 classic civic organizations (including only associations and foundations). The specialty of these organizations is the strong relationship with subsidies, and it seems that it has turned into subsidy dependence by now (2/3 of the incomes are subsidies), as a conclusion from the data of the Hungarian Statistical 
Office. This topic may also become sensible in a way, when an organization cannot account the received subsidies or cannot meet expectations of the judicial expectations, which all raises managerial control related concerns. It also highlights the relationship between civic organizations and control. In this study, we aim to cover some relevant specifications of the topic through the control, as a managerial function, and based on the results we may conclude that a higher ratio of organizations cannot really perform by the expectations.

\section{Bevezetés}

A plurális demokrácia világszerte megfigyelhető kiterjedésével összefüggően a társadalomtudományi érdeklődés is növekszik a civil szervezetek irányába. Abban a globális környezetben, ahol nemrég még a hatékonyság és a profit hegemóniáját figyelhettük meg, terjed és befolyásol a harmadik szektor világa. Noha Nyugaton a menedzsment irodalmak a 80-as években (pl. [1]) a globális társadalom, a harmadik szektor és a CSR területét még nem érintik, a '90-es évekre ez a terület olyan fontossá válik, hogy az alapok és a menedzsment történetét követően a fayoli 5-ösből [2] redukált 4 fő tevékenységet megelőzve készíti fel az olvasót a globális környezet különféle kihívásaira, így kulturális különbségekre, etikára, társadalmi felelősségvállalásra (pl. [3], [4]). Érdekes módon a menedzsment diszciplínával sok közös témában (pl. kultúra, csoportviszonyok, gazdaság, környezet) osztozó szociológia tudományában is hasonló módon jelentkezik a globalizáció problematikája, ahol az elméleti bevezetést követően az első fejezetek között foglal helyet a téma (pl. [5], [6]).

\section{A téma irodalmi megközelítése}

Az ellenőrzés vizsgálata nem mondható a legpreferáltabb, legkedveltebb vezetési funkciónak a hazai szakirodalmak terén, így például az egyik releváns szakirodalomban [7] ilyen fejezet nem is szerepel. A másik hazai mértékadó szakirodalom [8] az utolsó fejezet, a Teljesítmény keretében tárgyalja a Kontroll témakörét. Mind a hazai, mind a külföldi irodalmak ([8], [9]) az ellenőrzést/kontrollt a szervezeti célok elérésével látják összefüggésben, ahol az utóbbi szerint ennek elérése érdekében a szervezeti tevékenységeket szabályozni (regulation) kell, míg az elóbbi esetében a szervezeti egységek egyes jellemzőire a vezetők előzetesen standardokat állapítanak meg, melyek aktuális értékeit mérik és ös-szehasonlítják a standardokkal. Azaz, a célok és a tényleges működés eredményei közötti különbséget csökkentő, egyik legfontosabb vezetési funkció a kontroll, vagy ellenőrzés. A kontrolhoz számos pozitív és negatív asszociáció is kapcsolódik, ahol pozitív a rend, előreláthatóság, bizonyosság, és negatív a dominancia, erőszak, mások kihasználása. Típusai elsősorban a piaci, a bürokratikus és a klánkontroll ([8], amelyek közül a mi érdeklődésünk elsősorban a piacihoz áll a legközelebb, de nem a szó szoros értelmében. A szúkebb témánk, a hazai civil, ezen belül a sportcivil szervezetek ellenőrzése terén a szokásos piaci viszonyokról csakis részben beszélhetünk, itt ugyanis sok esetben a támogatás-, és nem a profitszerzés dominál. A KSH legutóbbi tájékoztatója szerint a sport cél szerinti tevékenységgel rendelkező nonprofitok esetében az állami támogatások abszolút értékben vett összege a legmagasabb az összes nonprofit között. Ez az összeg 2017-ben 183 376,5 millió Ft, sőt a sporttal foglalkozó klasszikus civil szervezetek önmagukban a klasszikusok bevételének 30,2\%-át teszik ki, az összes nonprofit bevételének több mint 10\%-át (11,02\%). A támogatások egyébként erősen áthatják a civil szervezeti szférát: ugyanez a KSH tájékoztató ír arról is, hogy a klasszikus civilek bevételeinek 64\%-a támogatás - 
minősítsük úgy, hogy erősen támogatás kitettek/támogatásfüggők. A sport cél szerinti tevékenységet választó sportcivileknél ez az arány még magasabb, összesen 72,1\%, ahol domináns az állami támogatás aránya (63,05\%). Amennyiben az állam a fő támogató, úgy nyilvánvalóan érdekelt egy megbízható és kiszámítható támogatási mechanizmus fenntartásában, és hasonlóképp várja ezt el az másik féltől is. Az állami oldal ugyanakkor nem csupán támogatói szerepben jelenik meg, meghatározóak a szervezeti regisztrációban, és nem csak a támogatáshoz kapcsolódó működési mechanizmus ellenőrzésében is (pl. adózási ellenőrzés, bírósági ellenőrzés). Ezek a momentumok különösen lényegesek tehát egyrészt akkor, amikor egy szervezet önállóan müködik, vannak alapbevételei, de még fontosabbak akkor, amikor az állam ilyen támogatási intenzitás mellett, kvázi fenntartói a sportcivil szervezeteknek. Az elmúlt időszakok sportcivil anomáliái, pl. TAO és egyéb támogatásokkal való elszámolás lehetetlensége egyes szervezetek esetében felkelti mind az állam, mind a kutatók érdeklődését, különösen akkor, ha nem aprópénzekről, hanem akár több százmilliós támogatásokról van szó [12]. Az, hogy a támogatások elérése, megtartása során több állami elvárás teljesítése is feltétel, teszi a problémát teljessé ahhoz, hogy foglalkozzunk a hazai civil szervezeti, különösen a hazai sportcivil szervezeti ellenőrzési sajátosságaival.

A civil szervezeti vezető vezetői funkciója ebben a tekintetben több szempontból is lényeges. A szervezeti beszámolók aláírói a civil szervezetek vezetői, azaz aláírásukkal hitelesítik a szervezeti működés sajátosságait. Azt tehát, hogy mikor és milyen tartalommal megy be a beszámoló, igen sok esetben maga a vezetői határozza meg: ismernie kell a beszámoló alapelemeit, a számszaki adatok helyességét ellenőrizni kell (a könyvelők a legtöbb esetben csupán rögzítik a tételeket és a mérleg és eredménykimutatás adatain túl a vezetőtől várják el a hiányzó információk megadását), sőt a beszámolók már a legtöbb esetben a vezető ügyfélkapuján/cégkapun keresztül kerülnek beküldésre. Ebben a folyamatban kikerülhetetlen az, hogy a vezetői ne lássa, ne tudja, hogy mi és hogyan kerül megadásra, közzétételre. Maga a vezető ebben a szférában szokásosan jogosult a szervezet képviseletére is, így a különféle ellenőrzési jellegű problémák során közreműködése megkerülhetetlen.

\section{A vizsgálat módszere}

A vizsgálat kiindulási alapját egy korábbi kérdőíves felvételezés jelentette. Babbie [13] szerint "Ma valószínűleg a kérdőíves felmérés a társadalomtudományokban leggyakrabban alkalmazott kutatási módszer." Ezek a vizsgálatok alkalmasak leíró, magyarázó és felderítő célokra." A korábbi empirikus kutatás mérőeszköze önállóan szerkesztett kérdőív, ami 30 kérdésben méri a vezetési funkciók sajátosságait, köztük 5 kérdés foglalkozott specifikusan a szervezeti ellenőrzéssel. A mintavétel tekintetében elmondható, hogy az alappopuláció a Hajdú-Bihar megyei civil szervezetek köre, ahol a megkérdezés módja részben személyes, részben postai. Az alacsony visszaküldési hajlandóság miatt az eredmények összesen 82 civil szervezeti vezető véleményét tükrözik, míg a vizsgálatban részt vevő civil szervezetek száma 61. Mivel ez összességében felderítő jellegű kutatásnak minősíthető, így annak megfelelően, azzal párhuzamosan szakértői célzott interjús felvételezés is történt. Ehhez a kérdőív témáival harmonizáló interjú-vezérfonal készült, és olyan megkérdezettek véleményét tükrözi, akik egyrészt jelentős tapasztalattal rendelkeznek a civil szervezetek működtetése, menedzselése terén (pl. volt CISZOK munkatárs, vagy épp a szervezetekkel foglalkozó pályázatíró, kamarai szakértő, közösségi ház vezető, valamint állami ellenőrzési hatóság szakértői is),összesen 15 szakértői interjút eredményezve. 
A korábbi kutatás eredményeit egészíti ki egy másik módszer, melyet alapvetően dokumentumelemezésnek lehet hívni. Ez szekunder forrásra alapozott empirikus munka, mely sajátossága, hogy a rendelkezésre álló törvényszéki online adatokat (sportcivil szervezetek törvényszéki honlapon közzétett beszámolóit) empirikusan elemezzük, az adatokat saját változókba rögzítjük, így az elemzés révén az eredeti adatok más célra lesznek összesítve. Ennek a módszernek a tevékenysége tehát 19 változó alapján Hajdú-Bihar megyei sportcivil szervezetek adatai lekérdezése manuálisan a törvényszék civil szervezeti adatbázisáról (www.birosag.hu), és eredménye ezáltal egy újabb adatbázis létrejötte. Az alappopuláció sporttevékenység esetében 367 egyesület és 19 alapítvány, sporttevékenység (pl. fizikai, stb.) esetében 143 egyesület és 8 alapítvány, ez képezi a törvényszéki adatbázist tekintve a hajdúbihari sportcivil szervezetek körét. Itt a mintavétel szisztematikus, ahol valamennyi sport- vagy sport (pl. fizikai, stb.) cél szerinti tevékenységgel foglalkozó Hajdú-Bihar megyében bejegyzett alapítványt lekérdeztünk, valamint sport cél szerinti tevékenység esetében minden 3., sport (pl. fizikai, stb.) cél szerinti tevékenység esetében minden 2. szervezet adatai lekérdezésre kerültek (az arányok okai az alappopulációban meglévő különbözőségek), a pótcímezés aránya alacsony maradt. A minta tehát ös-szességében 217 hajdú-bihari sport vagy sport (pl. fizikai, stb.) cél szerinti tevékenységgel rendelkező egyesület és alapítvány. Mindkét kutatás adatai SPSS rendszerbe kerültek rögzítésre, majd kiértékelésre. A 2 keresztmetszeti jellegű kutatásból igyekszünk a civil szervezetek ellenőrzési sajátosságaira rámutatni. A két kutatás összhangja mellett nem szabad elmenni a jelenlegi vonatkozások mellett sem, melyet a szerzők többéves tapasztalatai egészítenek ki.

\section{A vizsgálat eredményei}

Amennyire kiforrottnak tűnik a menedzsment diszciplínának a funkcionális megközelítése, a mai napig elnagyolt és felületes a szervezeti típusok megközelítése. A közgazdasági és mintzbergi tipológiák elsősorban a szervezetek felépítési és működési sajátosságain alapulnak, ugyanakkor azoknak az alapvető szervezeti típusoknak és minimális sajátosságaiknak az ismertetése, melyek globálisan jellemzőek (pl. ltd., plc., foundations, etc.), mindezidáig mintha elkerülte volna a menedzsment irodalmak szerzőinek figyelmét. A profitorientált szervezetek sajátosságai főként a szervezeti designhoz, míg a civil szervezetek témaköre főként a társadalmi felelősségvállalás, mint vezetési területhez kapcsolódva jelenik meg. A társadalmi felelősségvállalás során ír a nemzetközi irodalom (pl. [9]) a szervezeti müködés stakeholdereiről, akik olyan szereplők, akiket "közvetlenül érint a szervezeti működés, és akiknek érdeke a szervezeti teljesítmény."

A következő ábra (1. ábra) vázlatosan mutatja be ezeket a stakeholdereket/érintetteket, ahol a mi vizsgálatunk számára a bíróság és az állami, szövetségi szint a lényeges környezeti elem. 


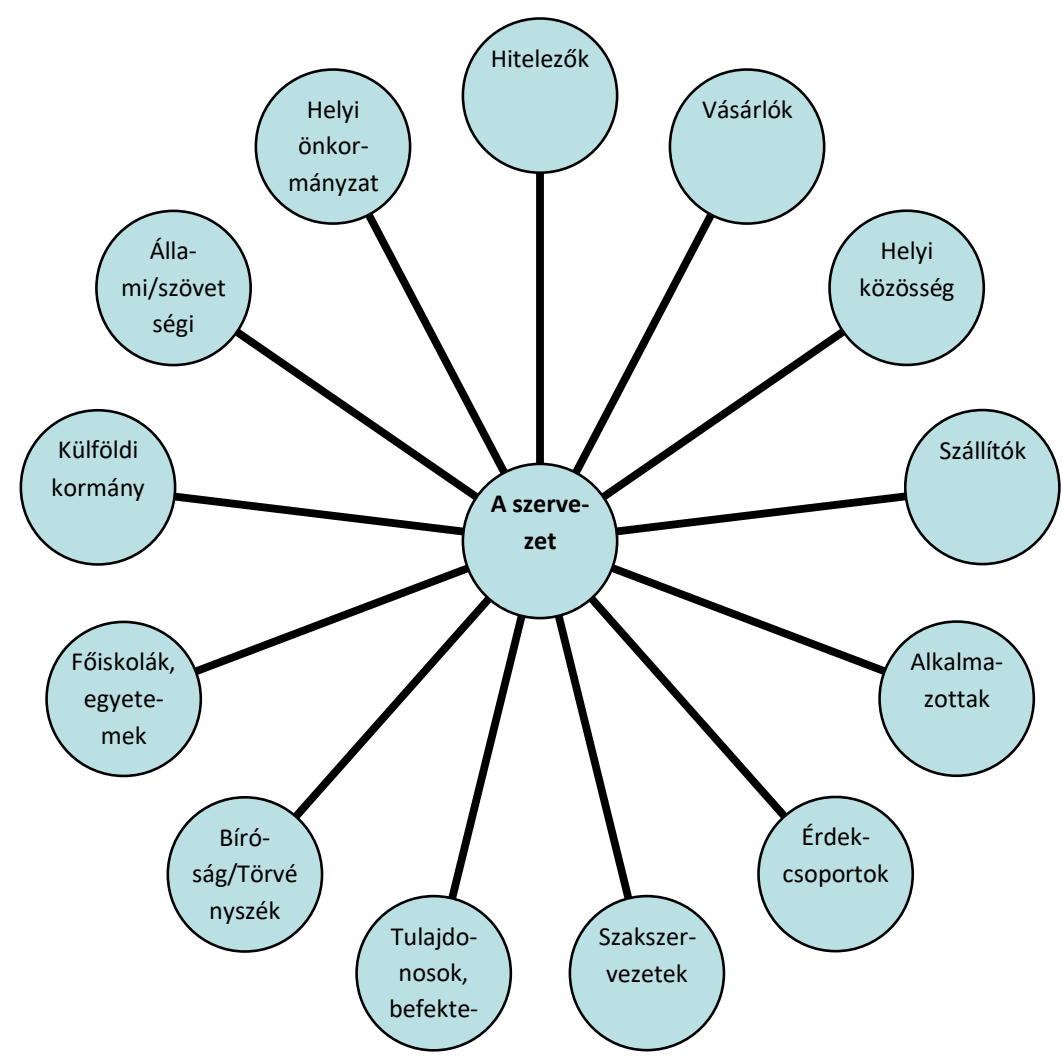

1. ábra: A szervezeti stakeholderek/érintettek köre

Forrás: [9] alapján saját szerkesztés, 2019

Az első kutatás során felvételezett interjúkból derült ki, hogy a jelenlegi működési környezetben a civil szervezetek ellenőrzése elsősorban két aspektusból érdekes. Az első aspektus a működés, annak sajátosságainak törvényességi ellenőrzése. 2015-ig a civil szervezetek bírósági adminisztrációs kötelezettségeivel kapcsolatosan több jogszabályt kellett megemlíteni: a 6/1989. IM rendeletet a civil szervezetek nyilvántartásának ügyviteli szabályairól, és a 12/1990. IM rendeletet az alapítványok nyilvántartásának ügyviteli szabályairól. 2011-ben két további lényeges jogszabály jelent meg, a 2011. évi CLXXV. törvény az egyesülési jogról, a közhasznú jogállásról, valamint a civil szervezetek működéséről és támogatásáról (Et., Ectv. vagy Civiltv.), illetve a 2011. évi CLXXXI. törvény a civil szervezetek bírósági nyilvántartásáról és az ezzel összefüggő eljárási szabályokról (Cnytv.). Ezeket egészíti ki a 350/2011. (XII.30.) Kormányrendelet a civil szervezetek gazdálkodása, adománygyüjtés, és a közhasznúság egyes kérdéseiről. Mára ehhez hozzáadódott az „új” Polgári Törvénykönyvről szóló 2013. évi V. törvény (Ptk.), , az ügyészségről szóló 2011. évi CLXIII. törvény (Ütv.), valamint lényegesek az egyes speciális támogatási formához kapcsolódó jogszabályi környezetet rendező egyes jogforrások (pl. NEA-Nemzeti Együttműködési Alap esetében a Civil tv., a helyi támogatásokkal összefüggésben a 2011. évi CLXXXIX. törvény Magyarország helyi önkormányzatairól, vagy épp a 2011. évi CXCV. törvény az Államháztartásról (Áht.) stb. ). Sajátos, hogy szinte ahány forma, annyi jogforrás, ezért nem is könnyű átlátni. A létrehozatallal kapcsolatos jogszabályok sajátosan keretjellegűek, a felmerülő joghézagokat pedig sokszor a bírósági gyakorlat tölti ki. A jogalkalmazási gyakorlat sokszor esetleges, jogértelmezési eltérések miatt érdemi kérdésekben akár különbözhet is, ami a szervezetek adminisztrációjának különböző- 
ségéhez is vezethet. A külső ellenőrzésnek az alapvető jogi kereteit tehát ezek a jogszabályok határozzák meg. Az különösen érdekes, hogy már a bejegyzés és a működés alapvető jogi feltételeinek men-nyire tudnak megfelelni a civil, ezen belül pedig a sportcivil szervezetek.

A korábban említett első empirikus kérdőíves vizsgálat eredményei arra mutatnak rá, hogy elsőként is a Berde [14] szerint meghatározott funkcionális menedzsment területek közül a Folyamatmenedzselés, melynek része az Ellenőrzés is, nem a legfontosabb vezetési dimenzió: ugyan az összes felmért civil esetében fontosabb, mint a HR menedzselés, de kevésbé fontos, mint a Szervezetmenedzsment (Likertskálán megítélése 4,09). A sport cél szerinti tevékenységű szervezetek esetében ez a szám valamelyest magasabb, 4,31 értéket kapott az ötös fokozatú Likert-skálán, de fontosságában maradt középen. A mintában résztvevők szerint a felmért szervezetek esetében túlnyomórészt a vezetői ellenőrzés jellemző, azaz az ellenőrzés leggyakrabban vezetői kezdeményezésre történik, és a tapasztalatok szerint nagyságrendekkel kevesebb a külső kezdeményezésre indított ellenőrzés. Az ellenőrzéssel kapcsolatosan felmerült a kérdés, hogy vajon milyen a megkérdezett vezetők attitűdje a szervezettel szemben támasztott elvárásokkal. Ezek alapján azt vizsgáltuk, vajon a vezetők mennyire ítélik a szervezet működését megfelelőnek (1-5 Likert skála alapján) az alapításkor megfogalmazott célokkal, a társadalmi elvárásokkal, a jogszabályi elvárásokkal, illetve az adminisztrációs elvárásokkal szemben. Az összes vezetőre vonatkozó adatokat tekintve elmondható, hogy a megkérdezett vezetők szerint szervezeteik legjobban a saját maguk által az alapításkor meghatározott szempontoknak tudnak megfelelni $(4,4)$. Kevésbé képesek a társadalom elvárásait teljesíteni $(4,1)$ és a jogszabályok követelményeinek eleget tenni $(4,1)$, legkevésbé pedig az adminisztrációs kötelezettségeket tudják teljesíteni. A minősítések átlagpontszáma elmarad az elvárttól, ami hiányosságokra enged következtetni. A szervezetek tehát elsősorban a saját elvárásaiknak felelnek meg, ennél talán fontosabb az, hogy a környezetük elvárásainak kevésbé. A sportcivilek kapcsán szervezeti sajátosságként elmondható, hogy a mi érdeklődésünk szempontjából fontos jogszabályi követelmények tekintetében a sportcivil szervezetek menedzserei sem igazán állnak jobban ezekkel az elvárásokkal kapcsolatosan (a vizsgálati eredményeket a 2. ábra mutatja be).

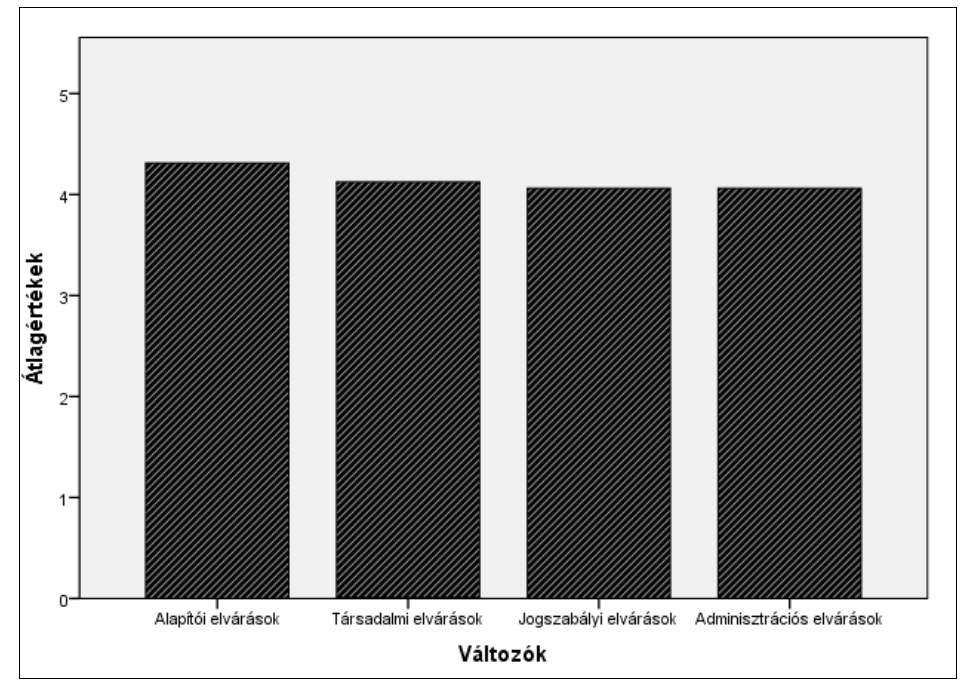

2. ábra: A jogszabályi és adminisztrációs elvárások elmaradása a vezetői megítélésben Forrás: Saját vizsgálatok, 2019. 
Az eredmények szerint valójában valamennyire rosszabbul is állnak a sportcivilek a jogszabályok követelményeinek való megfelelés terén $(4,06)$, és az adminisztrációs kötelezettségek 5 -ös listán történő szubjektív minősítése szintén 4,06. Ez már a szervezeti vezetők részéről is jelzi a hézagot, az elmaradást a formális, az állam által velük szemben támasztott követelmények teljesítésétől.

A jelenleg is folyamatban lévő kutatás több más sajátosság mellett igyekezett megtudni a szervezetek minimális jogi elvárásainak való megfelelőségét, nevezetesen az évente esedékes szervezeti beszámolók közzétételét. Ez már nem szubjektív, hanem az objektív valóság, és nem a vezetői véleményeken alapul, hanem a törvényi megfelelőségükkel kapcsolatos dokumentációjuk tartalmi elemzésén, azaz dokumentumelemzésen. Ennek egy igen jól illusztrálható példája az éves beszámolási kötelezettség teljesítése. A jelenlegi jogszabályi környezet szerint [15] a beszámolókat az Országos Bírósági Hivatal részére kell benyújtani (Cnytv. 39.§ (1) bek.), majd az elfogadást követően a www.birosag.hu-ra (Civil Információs Portál) feltöltésre kerül (Ectv. 30.§ (3) bek.). Ennek a jelenlegi szabályozás szerinti határideje minden év május 31. napja, ám a szabályozás megengedő, ha egy szervezet azt időben nem tette közzé, egy éve van a pótlásra. A beszámoló letétbe helyezése elmulasztásának következménye az Ectv. 30.§ (5) bekezdése szerint 10.000 Ft-tól 900.000 Ft-ig terjedő pénzbírság. Az Ectv. hatályba lépésével az előző évi beszámoló közzététele feltétele az állami támogatásnak (Ectv. 75.§: „2012. január 1. napját követően csak olyan civil szervezet kaphat költségvetési támogatást - ide nem értve az 54 . § szerinti támogatásokat -, amely a 30. § szerint letétbe helyezte beszámolóját"). Ez alapvető feltétel, mely elviekben tehát szervezetek tömegét zárhatná ki az állami támogatásból. A 2019. évben meghirdetett, de 2020-ra vonatkozó NEA ezt már előrébb hozza, ugyanis kiírásainál a 2018-as beszámolókat kéri, ami a törvényességi határidőn belül van, és elképzelhető, hogy emiatt szűkülni is fog a pályázók köre. Nézzük meg, hogy a 2019. május elején véget ért empirikus felvételezés adatait milyen beszámolási hajlandóságra és intenztitásra mutatnak rá. Lényeges ebből a szempontból, hogy nem a 2018-as beszámolók közzétételére kérdeztünk rá, ennek ugyanis, mivel mind az első határidő (tárgyév május 31.), mind a kiterjesztett, megengedő határidő (következő év május 31.) még nem jogkövetkezmény vonatkozású, így igazából tétje nincs. Annak ugyanakkor igen, hogy a 2017-es beszámolót 2018. május 31-ig kellett volna közzétenni, és mivel a felvételezés igen rövid idő alatt történt meg, és május 29-én zárult, így a 2017. évi beszámolók letétbe helyezési határideje napokon belül lejárt, így a kapott adatok elvileg már hű képet adhatnak arról, hogy mennyi szervezet és milyen mértékben nem tudja a letétbe helyezési követelményt részben, vagy egészében teljesíteni. Itt kell elmondani, hogy a lekérdezés szinte végig akadozott, melyet több alkalommal is jeleztünk a törvényszék felé, a hibaüzenetet is megjelölve. Ennek talán az akaratlan eredménye az is, hogy a lekérdezés utolsó elemei esetében a törvényszék a keresőrendszerét "kereskedelmi céllal történő nagymennyiségű adatletöltés miatt" 2019. május 28-át követően captcha védelemmel blokkolta, és jelenleg is blokkolja. Egyelőre nem tudni, hogy ez adatvédelmi aggályokat felvet-e (tapasztalatunk szerint igen labilis a rendszer, hiszen a captcha adatvédelmi ellenőrzés, a lámpák, kerékpárok, fák, autók stb. megjelölése esetében volt, hogy napokig még a jó válaszok ellenére sem tette lehetővé a civil szervezeti adatokhoz való hozzáférést). Egyértelmű, hogy a rövid időn belül általunk elindított lekérdezés a letöltésgát fő oka, ám az is bizonyos, hogy mivel a törvényszék vélhetően adatbázist nem készít a beszámolókból, jó eséllyel mi voltunk az utolsók, akik kutatási céllal el tudták érni megfelelő módon és időben a kívánt adatokat. Engedjük megjegyezni, hogy ez a törvényszék immár második olyan blokkja néhány éven belül, ahol a kutatási célú felvételezés, statisztikakészítés innentől gyakorlatilag ellehetetlenül. A fő kérdések ebben az összefüggésben mindenképp 
azok, hogy (1) a határidőig/időben a sportcivilek teljesítették-e 2017. évi tevékenységükről szóló beszámoló közzétételi (beszámoló letétbe helyezési) kötelezettségüket, (2) a 2017-es beszámoló letétbe helyezésének volt-e késése (3) hány beszámoló szerepel a bírósági adatbázisban (4)összességében megfelelő-e a beszámolók száma.

Az eredmények szerint az (1) esetet tekintve a lekérdezett 217 szervezet közül nagy többségük, 86,6\% közzétette a beszámolóját, érdemes hozzátenni ugyanakkor, hogy 29 szervezet nem. Érdekes (noha kevés az elemszám), hogy 22 mulasztó szervezet egyesület (az egyesületek 11,3\%-a), 7 pedig alapítvány (az alapítványok 41,1\%-a), azaz úgy tűnik, hogy alapítványi téren arányaiban több az ilyen jellegű probléma. Települési szinten tekintve 24 városi t és 5 vidéki szervezet nem tette közzé beszámolóját. A 31 közhasznú szervezet közül 3 nem tette közzé beszámolóját. Talán még annyit érdemes az eredményekhez hozzátenni, hogy ezek a szervezetek, sajátosságaiktól fogva jellemzően 1-es adószámúak, így ÁFA mentesek (ennek több oka van, hogy miért választják ezt). A 2017-es mintából 209 szervezet ÁFA mentes, és egy kivétellel itt van az összes mulasztó szervezet.

A (2) kérdés tekintetében úgy tűnik, hogy a be nem számoló szervezetek mellett igen jelentős a beszámolást késedelmesen teljesítő szervezetek száma is, az eredményeket itt szervezeti típus kereszttábla megbontásban mutatjuk be (3. ábra).

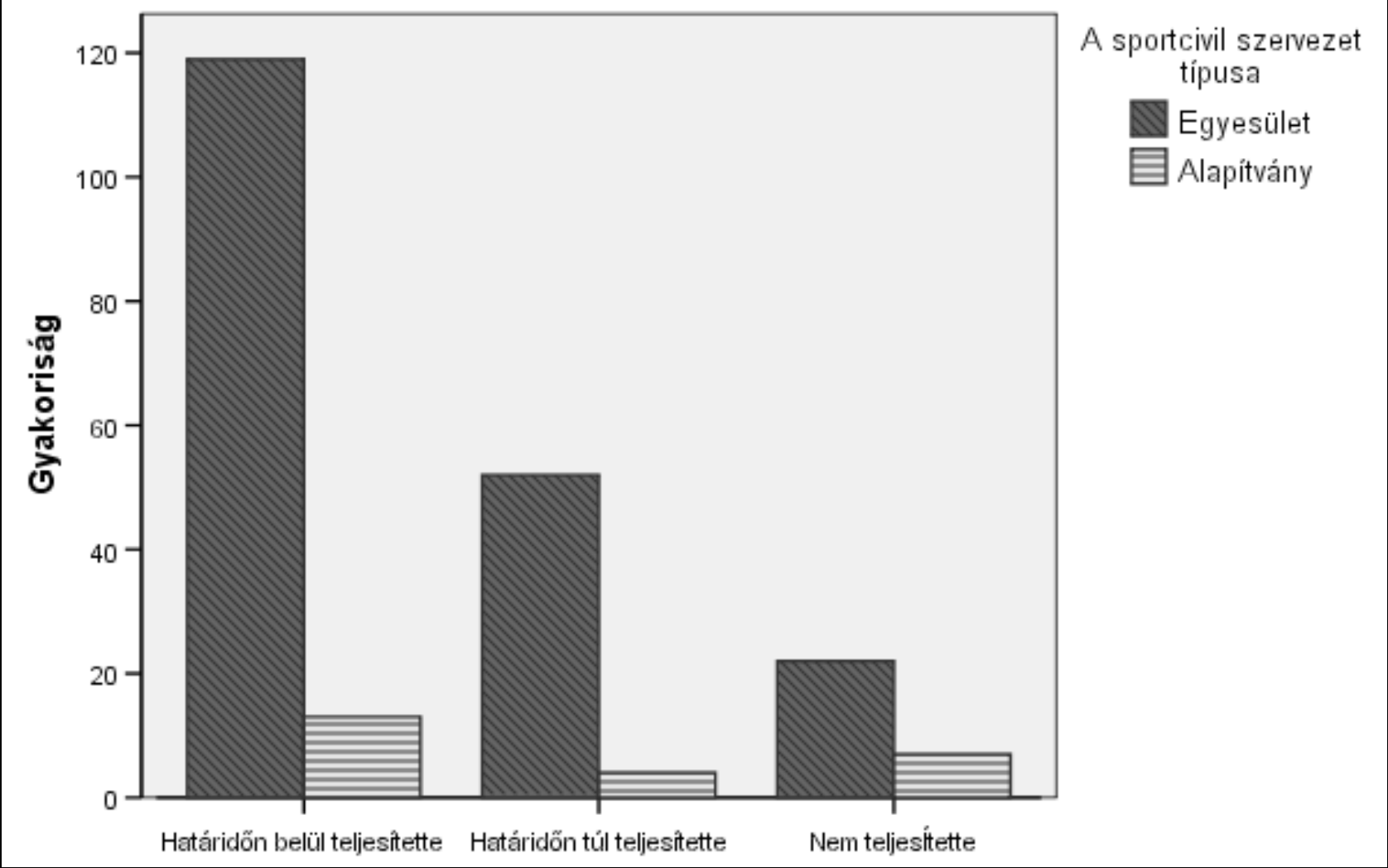

3. ábra: A szervezetek megoszlása szervezeti típus szerint a beszámolók közzételének időbeli összefüggésében (db) Forrás: Saját vizsgálatok, 2019.

Az eredmények alapján az látható, hogy a lekérdezett 193 egyesület közül 119 teljesítette időben ilyen jellegű kötelezettségét, a 24 alapítvány tekintetében ez a szám 13. A be nem számoló szervezetek 29 
darabos adata már ismert, így az igazi további eredmény az az 56 szervezet, akik a lekérdezett 217 közül késtek, arányuk 25,8\%. A nem teljesítő szervezeteket is ide véve, kijelenthető, hogy a szervezetek közel 40\%-a (39,1\%) enyhébb, vagy komolyabb beszámolási hiányosságokkal küzdenek. Érdekes lehet a bírósági keresőben meghatározott cél szerinti tevékenység alapján történő megoszlás, itt ugyanis létezik sporttevékenység és sport (pl. fizikai, szellemi, stb.) cél szerinti tevékenység attribútum is. Ennek a megkülönböztetésnek az oka számunkra egyelőre nem ismert, a bírósági kereső néhány évvel ezelőtt történő „fejlesztését” követően jelent meg ez a kategória. Az viszont érezhető, hogy egyaránt küzdenek a beszámolókkal. A lekérdezett 217 szervezet közel 2/3 a sima sport, 77 sport (pl. fizikai, szellemi, stb.) cél szerinti tevékenység kategóriájú, és míg az előbbinél 58:81-hez problémás és nem problémás az arány, addig ez utóbbi esetében 51:26 a nem problémás-problémás arány.

A következő, (3) vizsgálati szempont fő kérdése az volt, hogy vajon hány beszámoló szerepel a bírósági közzétételben, az érintett szervezeteket tekintve. Ez kevésbé ad képet arról, hogy mennyire felelnek meg a beszámolási kötelezettségnek, ám arról igen, hogy vajon a beszámolók száma alapján új, vagy inkább régebbi a szervezetek szakmai háttere, így volt-e idejük összességében alkalmazkodni a jogszabályi háttérhez. A közzétett beszámolók átlagos száma 5,66, ahol van olyan is, aki még nem tett közzé semmit, és van olyan is, aki már 9-et is közzétett. A standard eltérés itt 2,071, azaz voltak jelentős különbségek a szervezetek között. Az viszont vélhetően következik az eredményekből, hogy kevesebb az új belépő, a szervezetek jelentősebb részének tehát volt ideje felkészülni, és beszámolóik száma alapján régebb óta müködnek.

A vizsgálat nem vitásan egyik fő vizsgálati kérdése az, hogy (4) összességében megfelelő-e a beszámolók száma. Az eredmények szerint a felmért szervezetek közel 2/3-a (a szervezetek 63,65\%-a) esetében megfelelő a közzétett beszámolók száma, és nyilvánvalóan a maradék közel 1/3 (36,4\%) esetében a bírósági keresőben közzétett beszámolók száma nem elégséges. Az adatok arra is utalnak, hogy az egyesületek közel 2/3-a megfelelően teszi közzé a beszámolót, és csupán 1/3-uk nem, míg alapítványoknál a teljesítő és nem teljesítő szervezetek aránya épp 50-50\%. Ami viszont különösen érdekes, az az, hogy amikor összefüggésbe kívánjuk hozni a beszámolók számának megfelelőségét és a 2017-es beszámoló közzétételének meglétét, akkor azt találjuk, hogy a 79 szervezet esetében, ahol a beszámolók száma nem megfelelő, ott a 79 ily módon nem teljesítő szervezet közül 50 legalább közzétette a 2017-es beszámolót, viszont közel 40\% (36 szervezet) azt sem oldotta meg (azaz többszörösen is hibázott). A 2017-es beszámoló közzétételével kapcsolatos késés és a beszámolók száma közötti összefüggést a 4. ábra mutatja be. 


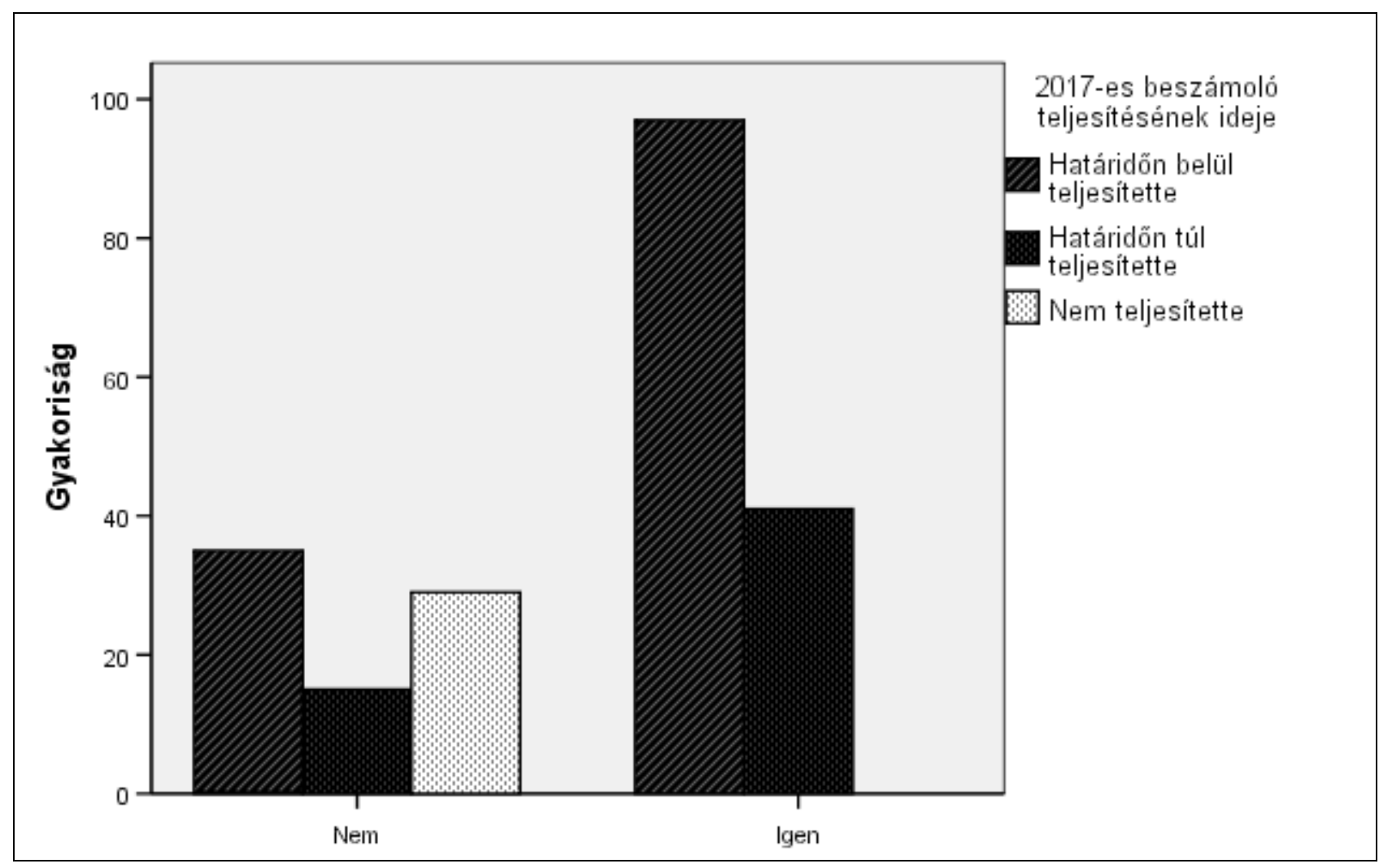

4. ábra: A szervezetek megoszlása 2017-es beszámoló közzétételének ideje és a beszámolók számának megfelelösége alapján $(\mathrm{db})$

Forrás: Saját vizsgálatok, 2019.

Az eredmények szerint jelentős a késők száma mind a megfelelőnek minősített (azaz a megfelelő számú beszámolóval rendelkező szervezetek), mind a nem megfelelőnek, azaz nem megfelelő számú beszámolóval rendelkező szervezetek között. Ahol ugyanis a beszámolók száma megfelelő (138 szervezet), még ott is 41 szervezet későn teljesít (tehát majd 30\%), míg ahol nem megfelelő a beszámolók száma, ott kis túlzással mondhatjuk, hogy majd ugyanannyi adta le határidőig a 2017-es beszámolót, mint amennyi nem teljesített(35 vs. 29), és a nem megfelelő mennyiségű beszámolóval rendelkező szervezetek közel ötöde (15 szervezet) határidőn túl teljesített.

\section{Következtetések}

Tanulmányunk középpontjában a Hajdú-Bihar megyei sportcivil szervezetek beszámolási kötelezettségeinek teljesítését igyekeztünk górcső alá venni, ahol főbb kérdéseink voltak: (1) a határidőig/időben a sportcivilek teljesítették-e 2017. évi tevékenységükről szóló beszámoló közzétételi (beszámoló letétbe helyezési) kötelezettségüket. (2) A 2017-es beszámoló letétbe helyezésének volt-e késése, (3) hány beszámoló szerepel a törvényszéki közzétételben, (4) összességében megfelelő-e a beszámolók száma. Az eredmények arra utalnak, hogy a szervezetek közel 15\%-a esetében lehet nem teljesítéssel, így jogi eljárási lépésekkel is számolni, azaz ilyen nagyságú jelenleg a nem teljesítők aránya. Továbbá, a felmért szervezetek közel negyede késéssel tud csak teljesíteni. A közzétett beszámolók száma alapján úgy gondoljuk, hogy kevesebb az új belépő, a szervezetek jelentősebb részének tehát volt ideje felkészülni a megváltozott jogi környezetre, mert beszámolóik száma alapján régebb óta mű- 
ködnek. A beszámolók száma alapján történő vizsgálat eredménye pedig összességében arra utal, hogy a szervezetek 2/3-a megfelelő számú beszámolót tett közzé, közel 1/3-uk viszont nem. Mind a 4 vizsgálati szempont teljesítési kötelezettséggel kapcsolatos elmaradásokra utal, ahol úgy tűnik, hogy kialakult egy, a működési környezet által előírt feltételeknek megfelelő réteg, és emellett létezik egy kisebb, színesebb réteg, ahol meg kell lennie az okoknak, hogy a szervezetek miért nem tudnak a minimális jogi előírásoknak megfelelően sem teljesíteni. Mivel ezeknek a feltételeknek a teljesítése több pályázat esetén minimum feltétel, így nem csoda, hogy ennek logikus következménye a forrásokhoz való hozzájutás blokkja, vagy akár további szabálytalanságokat is jelezhet.

\section{Hivatkozások}

[1] GRIFFIN, R. (1984): Management. Houghton Mifflin Co., Boston.

[2] DAFT, R.L. (1997): Management. 4th Ed. The Dryden Press., Fort Worth.

[3] FAYOL, H. (1984): Ipari és általános vezetés. Közgazdasági és Jogi Könyvkiadó., Budapest.

[4] WILLIAMS, C. (2009): Management. 6th Ed. South-Western Cengage Learning., Mason.

[5] ANDERSEN, M.L. - TAYLOR, H. F. (2011): Sociology. The Essentials. $6^{\text {th }}$ Ed. Wadsworth Cengage Learning., Belmont.

[6] FERRANTE, J. (2011): Sociology. A Global Perspective. 7th Enhanced Ed. Wadsworth Cengage Learning., Belmont.

[7] BAKACSI GY. (2004): Szervezeti magatartás és vezetés. Aula Kiadó., Budapest.

[8] DOBÁK, M. - ANTAL, ZS. (2010): Vezetés és szervezés. Szervezetek kialakítása és múködtetése. Aula Kiadó., Budapest. 422.p.

[9] GRIFFIN, R. (2013): Management. 11 th Ed. South-Western Cengage Learning., Mason. 101.p.

[10] KSH (2017): Nonprofit szervezetek 2017. http://www.ksh.hu/apps/shop.kiadvany?p kiadvany id=1043095\&p temakor kod=KSH\&p lan g=HU (letöltés időpontja: 2019.09.05)

[11] KSH (2019): A nonprofit szektor legfontosabb jellemzői, 2017. :http://www.ksh.hu/docs/hun/xftp/stattukor/nonprofit/nonprofit17.pdf (letöltés időpontja: 2019.09.05)

[12] Belebukott a TAO-ba a nyírbátori foci. https://szabolcsihir.hu/helybenjaro/2019/06/belebukott-a-tao-ba-a-nyirbatori-foci-amikor-a-sok-penz-is-nyug (letöltés időpontja: 2019.09.05)

[13] BABBIE, E. (2000) A társadalomtudományi kutatás gyakorlata. Balassi Kiadó, Budapest., 277278. p.

[14] BERDE CS. (2003) : Menedzsment a mezőgazdaságban, Szaktudás Kiadó Ház., Budapest.

[15] 479/2016. (XII.28.) Korm. rendelet 2.§ (1) bek. a) pont és III. fejezet 